\title{
CRYSTALLINE TEXTURE OF THE 2083 m ICE CORE AT VOSTOK STATION, ANTARCTICA
}

\author{
By V.YA. LIPENKOV, N.I. BARKOV, \\ (The Arctic and Antarctic Research Institute, Leningrad 199 226, U.S.S.R.) \\ P. Duval, and P. Pimienta
}

(Laboratoire de Glaciologie et Géophysique de l'Environnement, 38402 Saint-Martin-d'Hères Cedex, France)

ABSTRACT. Crystalline texture and $c$-axis orientation of the $2083 \mathrm{~m}$ ice core at Vostok Station, covering more than 150 kyear, reveal the existence of strong anisotropies. Changes in crystal size with depth are compatible with the growth of grains driven by the free energy of grain boundaries. A smaller growth rate appears to be associated with cold periods. A gradual increase in the horizontal elongation of grains was observed between 350 and $680 \mathrm{~m}$. But, the mean value of the coefficient of the linear dimensional orientation of grains does not change below $700 \mathrm{~m}$.

The $c$-axis orientation of ice grains tends to orientate perpendicular to the direction of the elongation of grains, forming a vertical girdle pattern. This characteristic fabric has been interpreted as resulting from the gradual rotation of grains by basal glide under uniaxial longitudinal tension. The rotation of grains was calculated with respect to the total strain, simulating the formation of the girdle fabric pattern. The fabric-enhancement factor was calculated at various depths. It appears that Vostok ice hardens gradually with depth when considering the transverse convergent flow. No significant variation of the enhancement factor was observed with changes in climate and impurity content.

\section{INTRODUCTION}

The analysis of crystalline texture in polar ice cores is of great importance in studying the flow of ice sheets. Studies on several deep ice cores from Antarctica and Greenland have revealed the development of highly preferred crystal orientation with depth (Gow and Williamson, 1976; Russell-Head and Budd, 1979; Herron and Langway, 1982; Herron and others, 1985). A clear relationship between the $c$-axis orientation and strain-rates has been verified both by in-situ measurements (RussellHead and Budd, 1979; Gundestrup and Hansen, 1984) and by laboratory studies (Lile, 1978; Duval, 1981; Duval and Le Gac, 1982; Pimienta and others, 1987; Shoji and Langway, 1987).

According to Azuma and Higashi (1985), the formation mechanism of the broad single maximum of the fabrics of the Dye 3 ice core (Greenland) is based on the rotation of $c$-axes by basal glide. A similar conclusion was reached by Pimienta and others (1987) for the Vostok core and by Fujita and others (1987) for the $700 \mathrm{~m}$ Mizuho core (Antarctica). This mechanism was also suggested by Alley (1988) to explain the strong single-maximum fabrics observed in several polar ice cores. This is possible as long as recrystallization processes do not occur intensively, i.e. at high stress and high temperature (Alley, 1988). Multiple-maxima fabrics observed in temperate glaciers are probably induced by recrystallization (Duval, 1981).

Such $c$-axis fabrics induced by intracrystalline glide are related to the deformation history of ice and to the stress state in ice sheets. Using the model developed by Azuma and Higashi (1985), an estimation of the accumulated strain in the Mizuho core at various depths was given by Fujita and others (1987). A detailed analysis of the relationship between the $c$-axis orientation and the flow of ice sheets was done by Alley (1988).

In this context, the $2083 \mathrm{~m}$ ice core recovered by the Soviet Antarctic Expeditions at Vostok Station (East Antarctica) is of fundamental importance because of the extremely low temperature and strain-rates.

In the present work, the ice-crystalline texture and fabrics of this core have been analyzed. No evidence of intense recrystallization was found along the $2083 \mathrm{~m}$ ice core. The ice seems to be mainly subjected to a tensile stress along a horizontal direction. Special attention has been focused on the relationship between the $c$-axis orientation and the enhancement factor.

\section{Vostok ice core}

The Soviet Antarctic station of Vostok is located in East Antarctica (lat. $78^{\circ} 28^{\prime} \mathrm{S}$., long. $106^{\circ} 48^{\prime} \mathrm{E}$.) at an altitude of $3488 \mathrm{~m}$. The mean annual temperature is $-55.5^{\circ} \mathrm{C}$ and the present snow accumulation is between 2.2 and $2.5 \mathrm{~g}$ $\mathrm{cm}^{-2}$ year $^{-1}$ (Young and others, 1982). The ice thickness is about $3700 \mathrm{~m}$. The age at the bottom of the core is estimated at $\approx 160$ kyear B.P. (Lorius and others, 1985). Thus, a climatic cycle is included in this ice core. The ice core was stored in a tunnel near the drilling site where the temperature was lower than $-50^{\circ} \mathrm{C}$. The texture analysis was done in a cold room at Vostok Station. Initial results on the ice structure and fabrics at Vostok were provided by Barkov (1973), Korotkevitch and others (1978), and Barkov and Lipenkov (1984).

\section{STRUCTURAL CHARACTERISTICS OF VOSTOK ICE}

\section{Crystalline texture}

The size and shape of the ice grains were determined from measurements on horizontal and vertical thin sections under a microscope. Crystal size was obtained by counting about 150 crystals within a given area of the thin sections. Measurements were done at the drilling site. The analysis of the preferred dimensional orientation of grains was done according to Saltykov's $(1961,1976)$ methods of directed and random secants. Below $100 \mathrm{~m}$, ice grains appear to be elongated along a horizontal direction. Thin sections were cut at each level along three planes denoted " $a b "$ ", " $a c$ ", and $" b c$ ". The " $c$ "-axis is vertical whereas the horizontal " $a "$-axis is along the direction of the elongation of the grains.

Changes in crystal size, with increasing depth, determined on 110 horizontal thin sections, are illustrated in Figure 1a. From a comparison of the crystal-size profile and the $\delta^{18} \mathrm{O}$ profile (Fig. 1c), it appears that the crystalgrowth rate is lower during the cold periods $B$ and $\mathrm{H}$ than during the warm periods $A$ and $G$. This result supports the relationship between the crystal-growth rate and climate or some factor correlated with climate found in the Dome C core (Petit and others, 1987). 


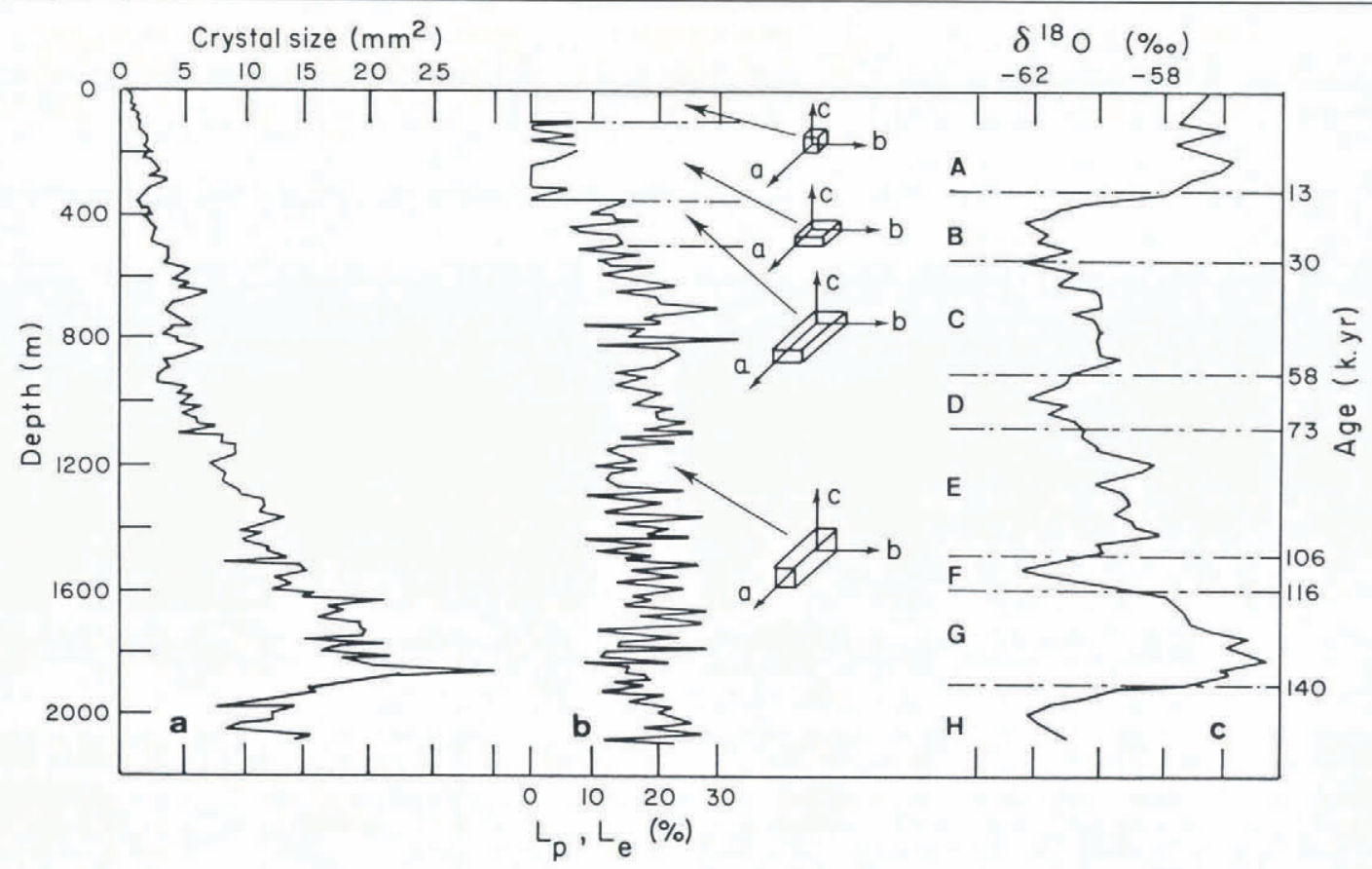

Fig. 1. Vostok ice-core profiles versus depth: (a) crystal size; (b) coefficients of orientation of grain boundaries and schematic illustration of the shape of grains; (c) isotope content ${ }^{18} O$ (from Lorius and others, 1985).

Figure $1 \mathrm{~b}$ shows the variation with depth of the coefficients of orientation of grain dimensions. $L_{\mathrm{p}}$ and $L_{\mathrm{e}}$ are respectively the coefficients of the planar and of the linear dimensional orientation of grains. They are defined as ratios of the oriented part of the specific surface to the total specific surface. The details of the procedure have been given by Saltykov $(1961,1976)$ and by Underwood (1970). $L_{\mathrm{p}}$ was calculated between the surface and $400 \mathrm{~m}$, whereas $L_{\mathrm{e}}$ was calculated below that depth. The horizontal elongation of grains clearly increases between 350 and $500 \mathrm{~m}$. The coefficient $L_{\mathrm{e}}$ reaches its maximum value at a depth of $680 \mathrm{~m}(\approx 28 \%)$ and broadly varies between 10 and $25 \%$ down to $2083 \mathrm{~m}$.

Changes in ice texture with increasing depth are illustrated in Figure 2. The variation of crystal size and shape of grains with depth is clearly revealed by these thin-section photographs. A characteristic of the crystalline texture is the near absence of interpenetrating crystals. Some

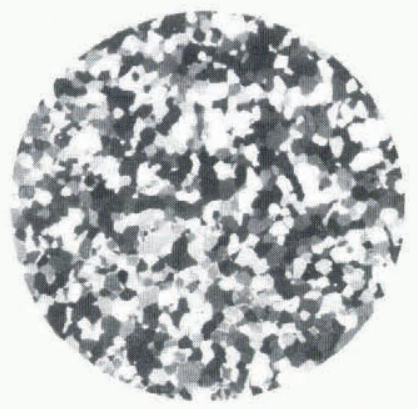

$387 \mathrm{~m} \stackrel{0}{\vdash} 1 \mathrm{~cm}$

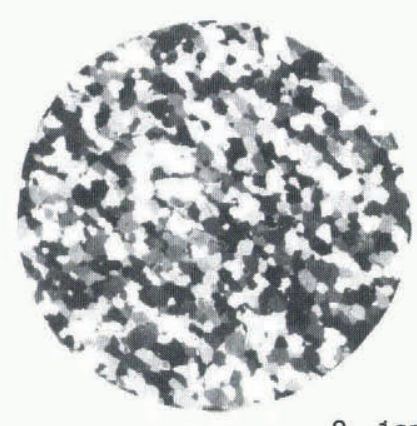

$592 \mathrm{~m}$

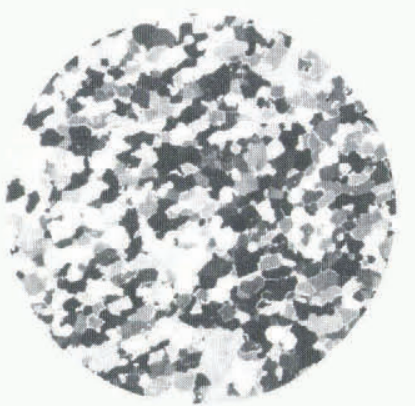

$925 \mathrm{~m}$

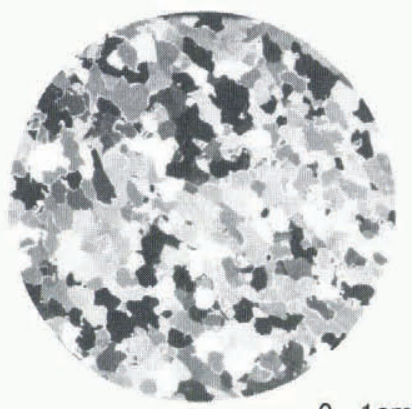

$1125 \mathrm{~m}$

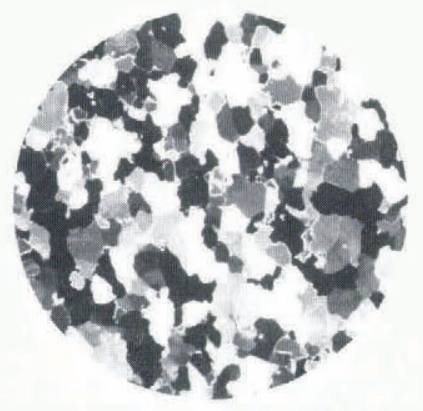

$1421 \mathrm{~m} \stackrel{0}{\stackrel{1}{1} 1 \mathrm{~cm}}$

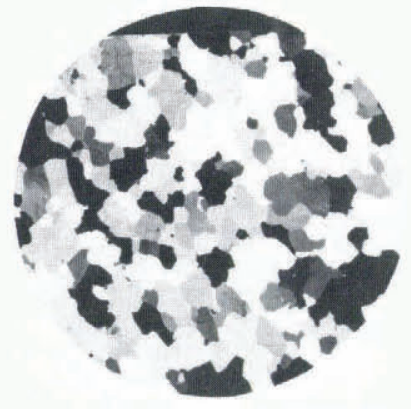

$1507 \mathrm{~m}$

$\overbrace{\vdash}^{0} 1 \mathrm{~cm}$

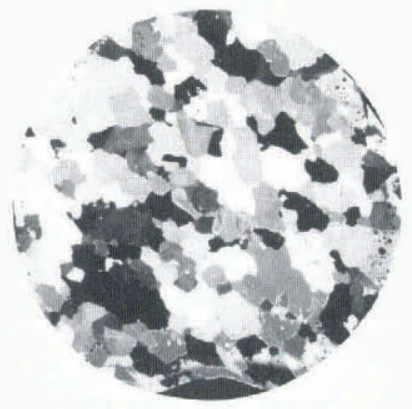

$1806 \mathrm{~m}$

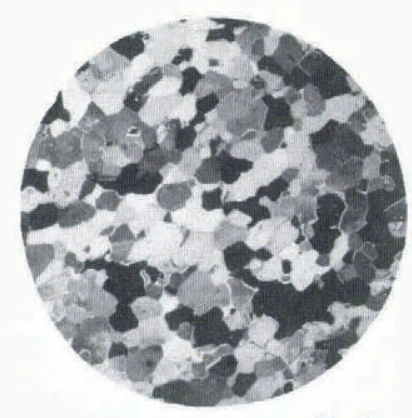

$2039 \mathrm{~m}$

Fig. 2. Thin-section photographs of the ice crystalline texture from the $2083 \mathrm{~m}$ Vostok core. These photographs were taken between crossed polaroids. 
crystals exhibiting undulose extinction can be seen below $900 \mathrm{~m}$. This crystalline texture and the relationship between the crystal-growth rate and climate support the assumption that grain growth driven by the free energy of grain boundaries occurs down to $2080 \mathrm{~m}$.

\section{Crystal orientation}

Crystal $c$-axis orientations were measured on a Rigsby universal stage. Results of the Vostok fabric analysis are presented in Figure 3. In the upper $350 \mathrm{~m}$ of the core, the $c$-axes appear to be quasi-uniformly distributed over the Schmidt equal-area net. A trend towards a clustering of $c$-axes around a vertical plane appears to start from a depth of $454 \mathrm{~m}$ and increases down to about $1000 \mathrm{~m}$ in depth. It is important to emphasize that the $c$-axis orientation does not exhibit a significant variation with the $\delta^{18} \mathrm{O}$ record below $1000 \mathrm{~m}$. On the other hand, the direction of the grain elongation is almost orthogonal to the vertical plane on which the $c$-axes are concentrated. This seems to suggest that Vostok ice is mainly deformed in tension along the horizontal " $a$ "-axis and that horizontal shear is of little significance along this core (Pimienta and others, 1987). Furthermore, as suggested by Pimienta (unpublished), it appears that grains are preferentially flattened in a plane
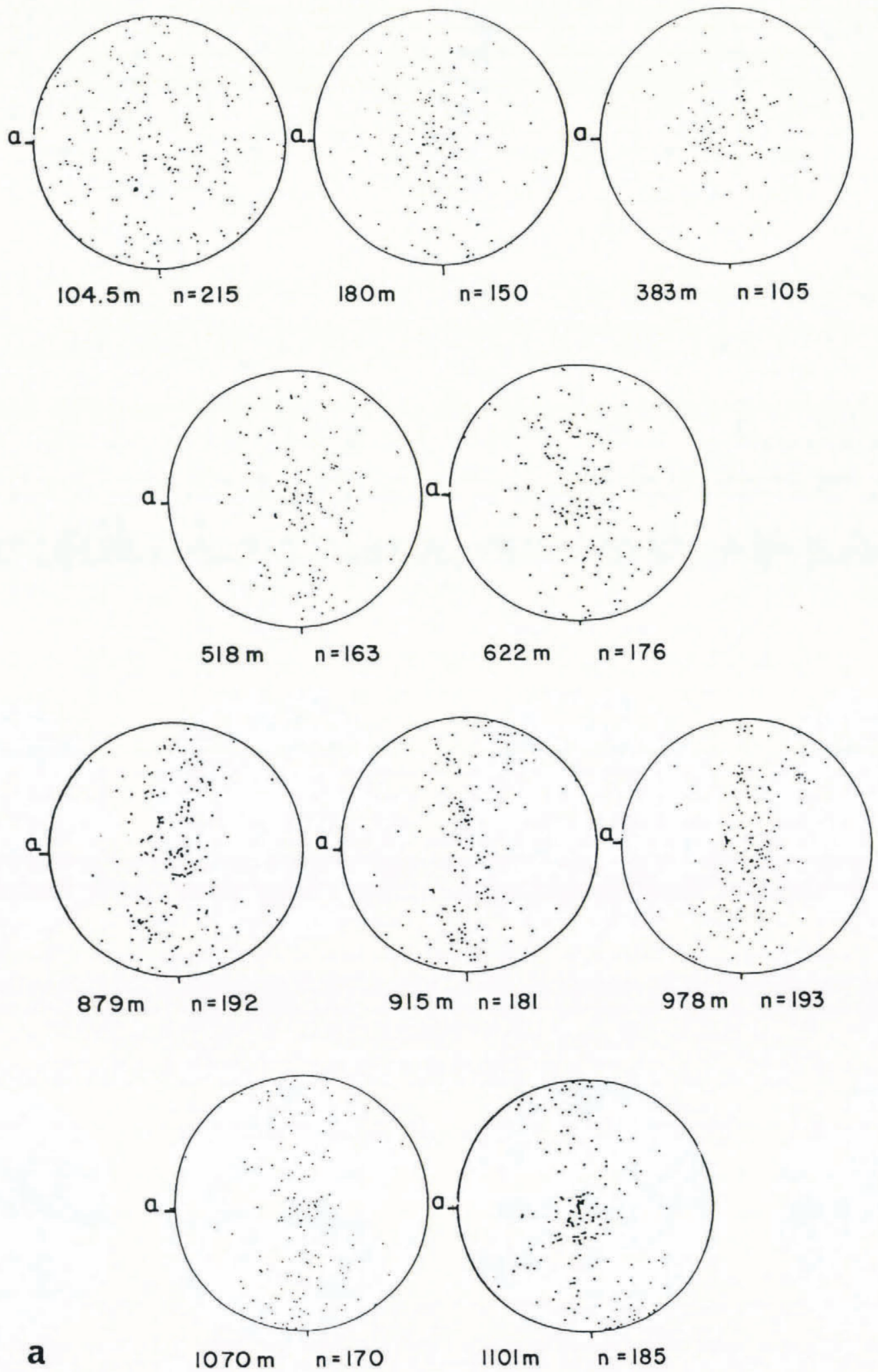

a

$1070 \mathrm{~m} \quad \mathrm{n}=170$

$1101 \mathrm{~m} \quad \mathrm{n}=185$

Fig. 3. Fabric diagrams for the Vostok ice core. The center of the fabric diagram represents the vertical direction. The number of c-axes measured is given below each diagram. The grain elongation is indicated by the "a"-axis. (a) 104.5-1101 m; (b) 1201-2080 m. 
perpendicular to the $c$-axis. This seems to indicate that basal glide occurs to a large extent. A broad singlemaximum fabric was observed in the same core at $494 \mathrm{~m}$ by Barkov (1973). The $c$-axis orientation of Vostok ice given in Figure 3 was confirmed by several measurements along the Vostok core at Grenoble (France).

\section{FORMATION PROCESSES OF CRYSTAL-ORIENTATION FABRICS}

\section{Deformation mechanisms}

The development of the preferred orientation of $c$-axes in polar ice must be investigated in relation to the deformation mechanisms of polycrystalline ice at low stresses. At Vostok, assuming that the vertical strain-rate $\dot{\varepsilon}_{z z}$ is uniform along the core and a steady state, $\dot{\varepsilon}_{z z}$ is given by:

$$
\dot{\varepsilon}_{z z}=b / H
$$

where $b$ is the accumulation rate and $H$ is the ice thickness. By taking an average value of $2.3 \mathrm{~g} \mathrm{~cm}^{-2}$ year $^{-1}$ for the present accumulation rate, the vertical strain-rate is about $7 \times 10^{-6}$ year $^{-1}$.

The horizontal shear strain-rate can be estimated by assuming a flow law with $n=3$. With a surface slope of $1 \times 10^{-3}$, the horizontal shear stress at $2000 \mathrm{~m}$ is lower than
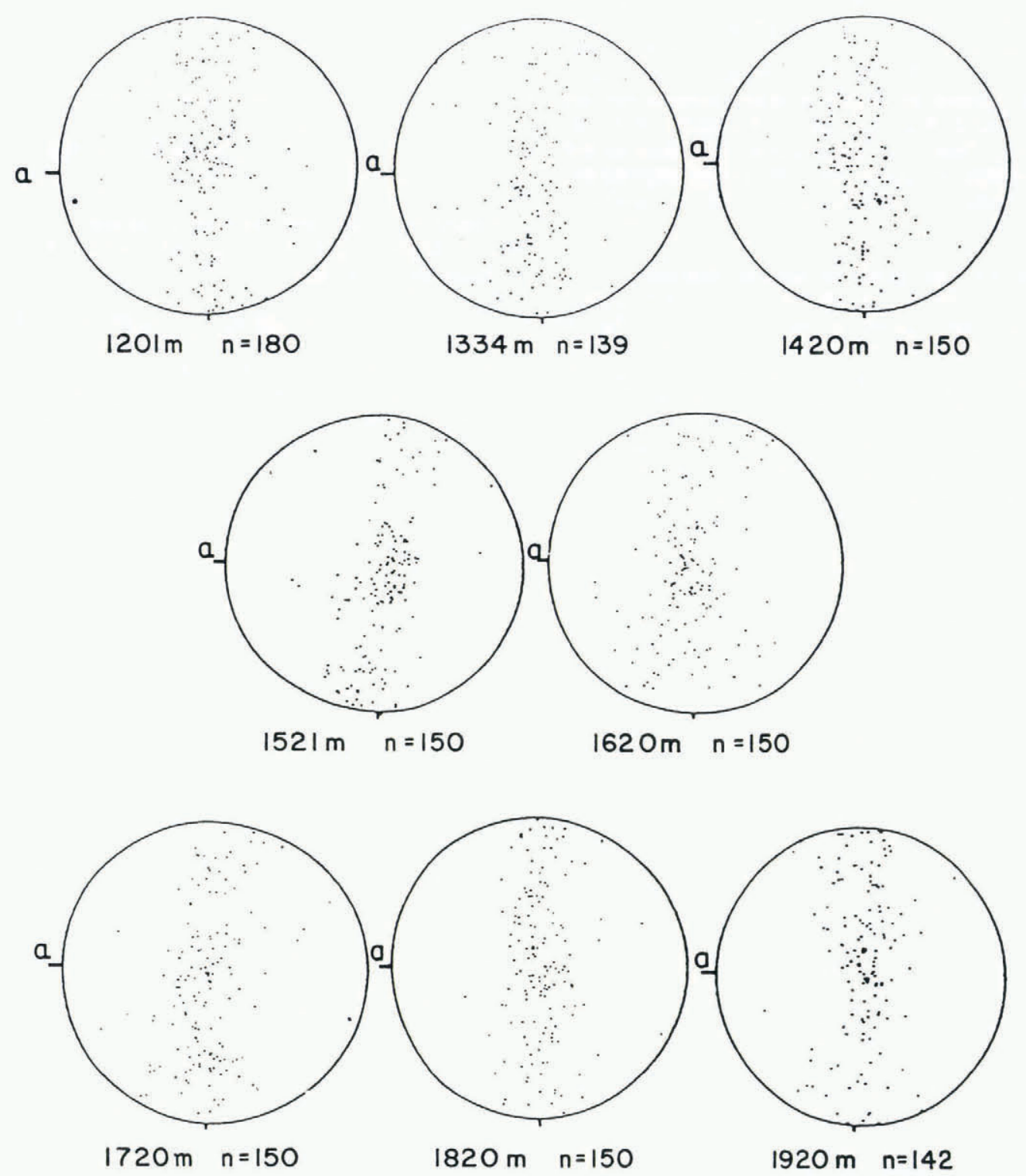

b

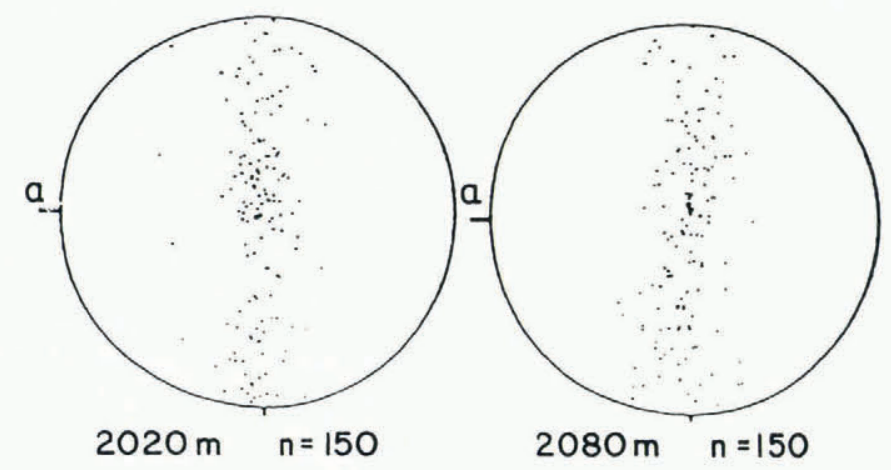


$0.02 \mathrm{MPa}$. By adopting the flow-law parameter of Duval and Le Gac (1982), the shear strain-rate is of the order of $4 \times 10^{-6}$ year $^{-1}$ at $-36^{\circ} \mathrm{C}$, i.e. at the temperature of the bottom of the core (Vostretsov and others, 1984). For these low strain-rates, diffusional creep with $n=1$ is expected (Duval and others, 1983). According to laboratory tests conducted at low stresses (Pimienta and Duval, 1987) and to analysis of inclinometer surveys of deep bore holes (Doake and Wolff, 1985; Lliboutry and Duval, 1985; Pimienta and Duval, 1987), a quasi-Newtonian viscosity would be expected for the ice-sheet flow near Vostok Station at least down to $2080 \mathrm{~m}$. But diffusional creep yields a viscosity much higher than that deduced from field data (Lliboutry and Duval, 1985). According to Fukuda and others (1987), the contribution of the Nabarro-Herring diffusion mechanism to the deformation of polycrystalline ice is very small in comparison with the contribution of the climb mechanism of dislocations on the basal plane. On the other hand, the continuous grain-boundary migration associated with grain growth appears to be an efficient process for the accommodation of intracrystalline dislocation glide (Pimienta and Duval, 1987). Thus, by considering the relationship between the elongation of grains and the $c$-axis orientation, basal glide is probably the dominant deformation mode of Vostok ice.

\section{Rotation of $c$-axes by basal glide in uniaxial tension}

By absorbing lattice dislocations, grain-boundary migration impedes strain hardening so that the rotation of $c$-axes by dislocation glide is made easier. As long as only basal glide is active and the grain-boundary constraint is minimized, the lattice rotation can be estimated. In the case of compression, the $c$-axis rotates towards the compression axis. Azuma and Higashi (1985) and Alley (1988) have shown that the random fabric of polycrystalline ice is transformed into a broad single-maximum fabric when ice is deformed in uniaxial compression. In the case of tension, the $c$-axis rotates away from the tensile axis. Figure 4 shows a schematic drawing of the deformation process of a single crystal under uniaxial tension. The rotation of the $c$-axis of each grain can be deduced from the equation:

$$
\cos \theta=\cos \theta_{0} \frac{l_{0}}{l}
$$

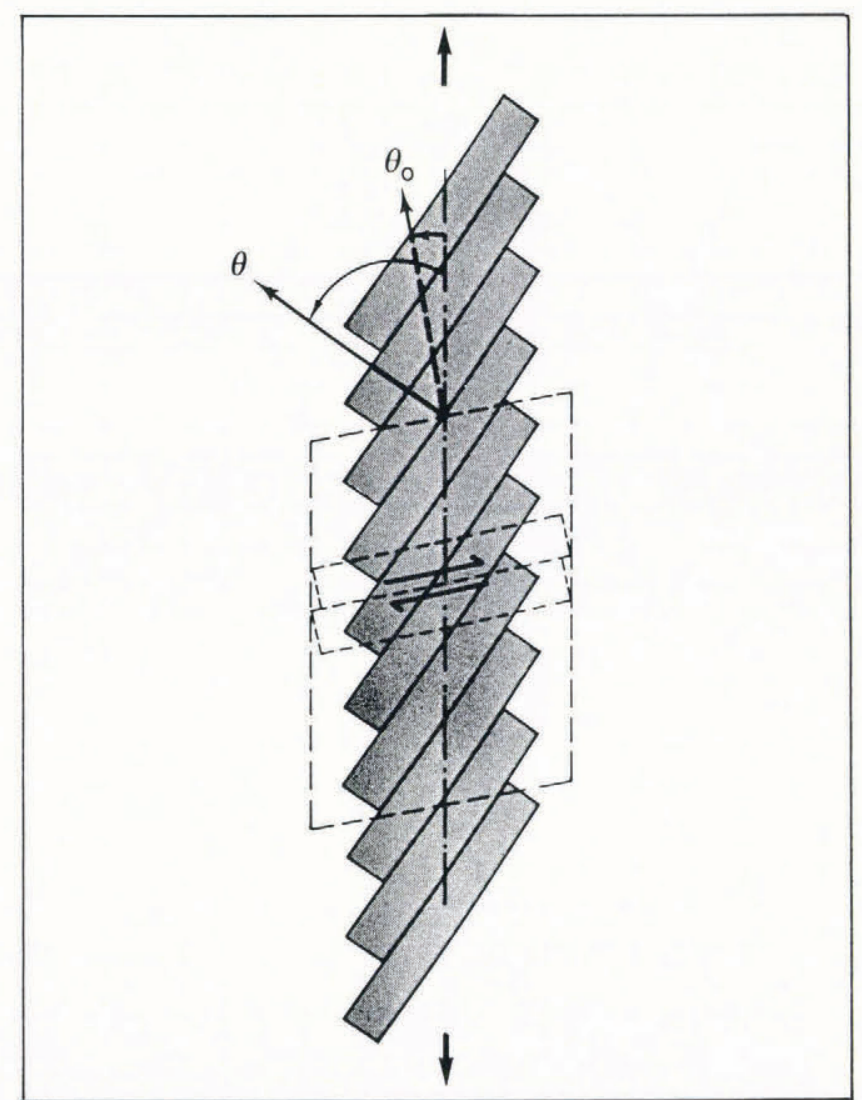

Fig. 4. Schematic diagram showing the rotation of the $\mathrm{c}$-axis of a single crystal of ice deformed in tension. where $\theta_{0}$ and $\theta$ are the angles between the $c$-axis and the tensile axis before and after elongation; $l_{0}$ and $l$ are respectively the initial and final lengths of the sample.

After deformation under uniaxial tension, the resulting fabric would be a great circle perpendicular to the tensile axis, i.e. similar to that exhibited by the Vostok ice core.

The simulation of the fabric development through $c$-axis rotation under uniaxial tension can be done by assuming that the bulk strain $\varepsilon$ is equal to the arithmetic means of the strain $\varepsilon_{g}$ of grains (Azuma and Higashi, 1985; Fujita and others, 1987). According to Fujita and others, the relationship between the strain increments $\Delta \varepsilon_{\mathrm{g}}$ and $\Delta \varepsilon$ is given by:

$$
\Delta \varepsilon_{\mathrm{g}}=A \Delta \varepsilon\left(\sin \theta_{0} \cos \theta_{0}\right)
$$

with

$$
A=\frac{N}{\sum_{i=1}^{N}\left(\sin \theta_{0 i} \cos \theta_{0 i}\right)}
$$

where $N$ is the total number of grains.

Since $l / l_{0}=1+\Delta \varepsilon_{g}$, Equation (2) combined with Equation (3) gives:

$$
\cos \theta=\cos \theta_{0}\left(1+A \Delta \varepsilon \sin \theta_{0} \cos \theta_{0}\right)^{-1} .
$$

Equation (4) gives the rotation of crystals induced by a small increment of the sample strain $\Delta \varepsilon$. Figure 5 shows the change of the $c$-axis orientation of an initially isotropic ice

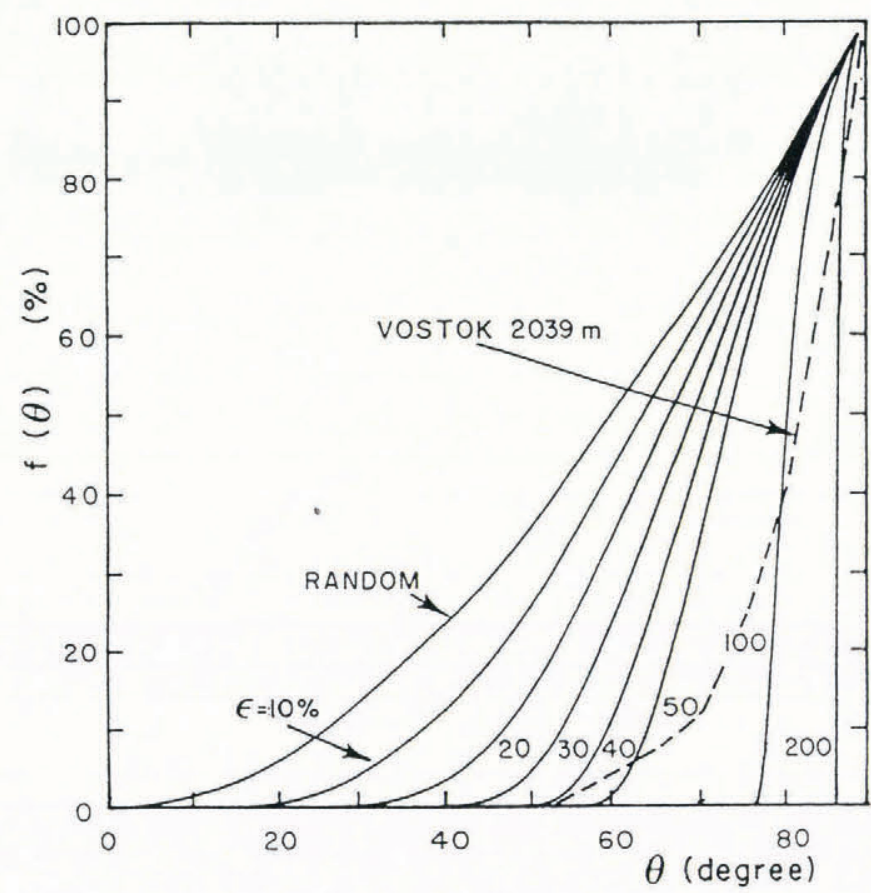

Fig. 5. Cumulative fraction $f(\theta)$ curve for the fabrics of Vostok ice at $2039 \mathrm{~m}$ and simulated curves under tension. $f(\theta)$ is the number of c-axes within a misorientation angle $\theta$ between the $\mathrm{c}$-axis and the tensile stress axis.

sample as the tensile strain increases. The simulation was carried out with a step $\Delta \varepsilon$ of $2 \%$ and $N$ was taken equal to 100. The curve $f(\theta)$ for the fabrics of Vostok ice at a depth of $2039 \mathrm{~m}$ is given for comparison. This figure shows the rapid concentration of $c$-axes in a plane perpendicular to the tensile axis as the total strain increases. An accumulated strain higher than 1 is therefore expected for the Vostok ice sample. This is in accordance with a vertical strain-rate of about $7 \times 10^{-6}$ year $^{-1}$ at Vostok and an age for this ice greater than 100000 years. A relatively good agreement is obtained between the simulated fabric pattern and that measured on the Vostok core. But, Equation (4) describing the formation of fabrics in the Vostok core can be questioned. Indeed, this equation was obtained from 
compressive deformation experiments on thin sections of polycrystalline ice and strain-rates were higher than $10^{-7} \mathrm{~s}^{-1}$ (Azuma and Higashi, 1985). At Vostok, the vertical strain-rate should be lower than $10^{-12} \mathrm{~s}^{-1}$. But, in spite of low stresses involved in the deformation of polar ice, dislocation glide is the dominant deformation mode. On the other hand, the incompatibility of the ice-grain deformation is reduced by the grain-boundary migration (Pimienta and Duval, 1987). This may explain the relatively good agreement between field data and the results deduced from the model developed by Azuma and Higashi (1985).

\section{FABRIC-ENHANCEMENT FACTORS}

The variation with depth of the $c$-axis orientation at Vostok indicates that the ice, down to a depth of $2080 \mathrm{~m}$, is mainly subjected to a uniaxial tensile stress along a horizontal direction. The orientation of the tensile stress with respect to the flow direction could not be deduced because the geographical orientation of the Vostok core had not been determined in situ, but a transverse convergent flow is expected (Alley, 1988). The rotation of the $c$-axes by dislocation glide makes ice hardness increase with tensile strain. The fabric-enhancement factor in tension can be estimated from Equation (4). The tensile strain-rate is proportional to the average geometric factor (the Schmidt factor) $\bar{S}$ given by:

$$
\bar{S}=\frac{1}{N} \sum_{i=1}^{N}\left(\sin \theta_{i} \cos \theta_{i}\right) .
$$

Figure 6 shows the variation of this factor with depth. It was determined from the fabric patterns given in

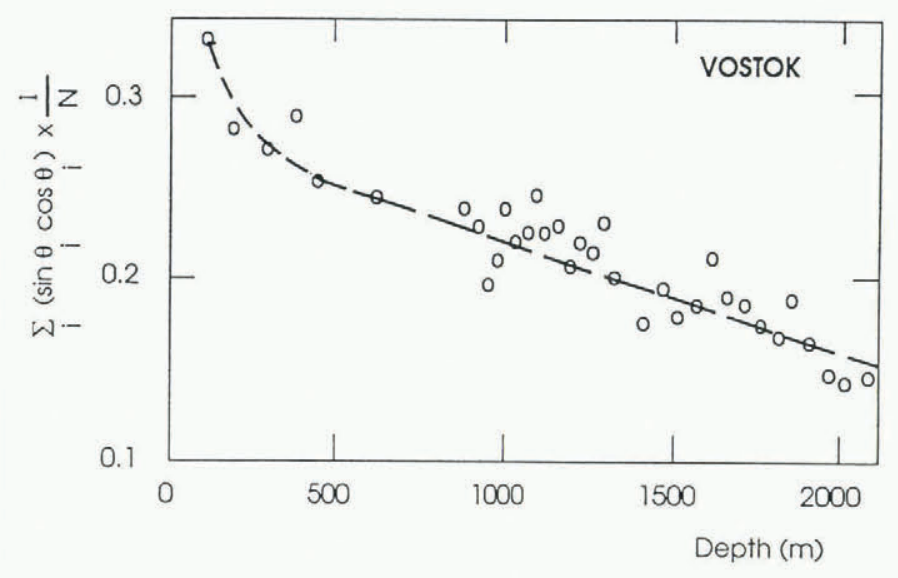

Fig. 6. Variation of the average Schmidt factor

$$
\bar{S}=\frac{I}{N} \sum_{i=1}^{N}\left(\cos \theta_{i} \sin \theta_{i}\right)
$$

with depth at Vostok.

Figure 3. It is divided by 2.2 between the surface and $2080 \mathrm{~m}$. The limited amount of data does not allow detection of any correlation between the fabric-enhancement factor and climate. In another way, the viscosity of the Vostok ice does not exhibit significant variations with climate (Pimienta and others, 1988). The same enhancement factor was found for two samples from the interglacial stage (depth: $1852 \mathrm{~m}$ ) and the previous glacial stage (depth: $2039 \mathrm{~m})$.

On the other hand, the Holocene-Wisconsin boundary in the Byrd ice core (Antarctica) and in the Camp Century and Dye 3 ice cores (Greenland) was identified by simultaneous sharp changes in the $c$-axis orientation and crystal size. A strongly preferred, nearly vertical, $c$-axis orientation was observed in glacial ice (Gow and Williamson, 1976; Herron and Langway, 1982; Herron and others, 1985). This kind of fabric is explained by the rotation of basal planes by the horizontal shear (Gow and Williamson, 1976).
The shear strain-rate enhanced by the vertical orientation of $c$-axes can be greater than $10^{-2}$ year $^{-1}$ (Dahl-Jensen and Gundestrup, 1987). At Dye 3, the enhancement factor for shear deformation along the horizontal plane varies between 5 and 12 in Wisconsin ice and 1 and 5 in Holocene ice (Shoji and Langway, 1987). The correlation between the $c$-axis fabric and climate is also associated with the impurity content. High impurity content is found in glacial ice in comparison with that in Holocene or interglacial ice (Legrand and others, 1988). A possible effect of impurities on the enhancement factor was put forward by Shoji and Langway (1984).

To understand the absence of such correlations in the Vostok ice core, the implication of the decrease of the fabric-enhancement factor as the tensile strain increases in the mechanical behavior of ice layers is analyzed below.

For a given interval of time and a constant horizontal tensile stress, the rotation of $c$-axes by basal glide is higher and the hardening greater where the ice viscosity is lower. This shows that any impurity-induced difference in the ice viscosity between two adjacent layers would diminish with time.

This could explain, on the one hand, the slight changes in the $c$-axis orientation and, on the other hand, the non-detectable variation in the ice viscosity (Pimienta and others, 1988) between 1500 and $2080 \mathrm{~m}$ in the Vostok ice core in spite of climatic changes and important variations in the impurity content.

By considering a constant strain-rate condition for axial strain, the fabric-strength feed-back cannot magnify any difference in the ice viscosity between two adjacent layers.

An opposite result would be obtained if ice was deformed in simple shear. Indeed, basal glide is enhanced as the orientation of $c$-axes rotates towards the normal to the permanent shear plane, and any difference between the ice viscosity in two adjacent layers will magnify with time. In ice sheets, the horizontal shear stress is imposed by the surface slope and the weight of the overlying ice mass. An instability can be initiated if small differences in the ice viscosity are present in the upper layers. This may explain the large variations in the $c$-axis orientation associated with changes in climate, crystal size, and impurity content observed in several ice cores.

\section{CONCLUSION}

This work represents the first complete study of icecrystalline texture from a deep ice core covering more than 150 kyear. Grain growth, driven by the free energy at grain boundaries, occurs down to $2080 \mathrm{~m}$. This is in accordance with the low strain-rates in the first $2080 \mathrm{~m}$ of ice at Vostok. The elongation of grains along a horizontal direction, combined with $c$-axes oriented perpendicular to it, has been interpreted as resulting from basal glide induced by a tensile stress applied in the same direction. The rotation of $c$-axes by dislocation glide makes ice hardness increase with the tensile strain. The Vostok core should be dated by taking into account this slow decrease of the fabric-enhancement factor. The fabric-enhancement factor does not appear to be significantly related to the impurity content or climate.

The Vostok ice core offers the possiblity of determining the ice-flow law at very low strain-rates $\left(<10^{-12} \mathrm{~s}^{-1}\right)$. There is clear evidence that dislocation glide is the dominant deformation mode of Vostok ice.

\section{ACKNOWLEDGEMENTS}

We are very grateful to all Soviet participants in the drilling. We acknowledge the Soviet Antarctic Expeditions for logistic support. This work was supported in the U.S.S.R. and at Vostok by the Soviet Antarctic Expeditions and in France by the Centre National de Recherche Scientifique.

\section{REFERENCES}

Alley, R.B. 1988. Fabrics in polar ice sheets: development and prediction. Science, 240, 493-495. 
Azuma, N. and A. Higashi. 1985. Formation processes of ice fabric pattern in ice sheets. Ann. Glaciol., 6, $130-134$.

Barkov, N.I. 1973. Rezul'taty issledovaniya skvazhiny i ledyanogo kerna na Stantsii Vostok v 1970-1972 [Results of the study of the borehole and ice core at Vostok Station, 1970-1972]. Materialy Glyatsiologicheskikh Issledovaniy. Khronika. Obsuzhdeniya 22, 77-81.

Barkov, N. and V. Ya Lipenkov. 1984. Kolichestvennaya kharakteristika struktury l'da do glubiny $1400 \mathrm{~m} \mathrm{v}$ rayone Stantsii Vostok v Antarktide [Numerical characteristics of ice down to a depth of $1400 \mathrm{~m}$ in the region of Vostok Station, Antarctica]. Materialy Glyatsiologicheskikh Issledovaniy 51, 178-186.

Dahl-Jensen, D. and N.S. Gundestrup. 1987. Constitutive properties of ice at Dye 3, Greenland. International Association of Hydrological Sciences Publication 170 (Symposium at Vancouver 1987 - The Physical Basis of Ice Sheet Modelling), 31-43.

Doake, C.S.M. and E.W. Wolff. 1985. Flow law for ice in polar ice sheets. Nature, 314(6008), 255-257.

Duval, P. 1981. Creep and fabrics of polycrystalline ice under shear and compression. J. Glaciol., 27(95), 129-140.

Duval, P. and H. Le Gac. 1982. Mechanical behaviour of Antarctic ice. Ann. Glaciol., 3, 92-95.

Duval, P., M.F. Ashby, and I. Anderman. 1983. Ratecontrolling processes in the creep of polycrystalline ice. $J$. Phys. Chem., 87(21), 4066-4074.

Fujita, S., M. Nakawo, and S. Mae. 1987. Orientation of the $700-\mathrm{m}$ Mizuho core and its strain history. In Matsuda, T., ed. Papers presented at the "Ninth Symposium on Polar Meteorology and Glaciology", held at the National Institute of Polar Research, Tokyo, December 11-12, 1986. Tokyo, National Institute of Polar Research, 122-131. (Proceedings of the NIPR Symposium on Polar Meteorology and Glaciology 1.)

Fukuda, A., T. Hondoh, and A. Higashi. 1987. Dislocation mechanisms of plastic deformation of ice. J. Phys. (Paris), 48, Colloq. C1, 163-173. (Supplément au 3.)

Gow, A.J. and T. Williamson. 1976. Rheological implications of the internal structure and crystal fabrics of the West Antarctic ice sheet as revealed by deep core drilling at Byrd Station. CRREL Rep. 76-35.

Gundestrup, N.S. and B.L. Hansen. 1984. Bore-hole survey at Dye 3, south Greenland. J. Glaciol., 30(106), $282-288$.

Herron, S.L. and C.C. Langway, jr. 1982. A comparison of ice fabrics and textures at Camp Century, Greenland and Byrd Station, Antarctica. Ann. Glaciol., 3, 118-124.

Herron, S.L., C.C. Langway, jr, and K.A. Brugger. 1985 Ultrasonics velocities and crystalline anisotropy in the ice core from Dye 3, Greenland. In Langway, C.C., jr, H. Oeschger, and W. Dansgaard, eds. Greenland ice core: geophysics, geochemistry and the environment. Washington, DC, American Geophysical Union, 23-91. (Geophysical Monograph 33.)

Korotkevich, Ye. S., V.N. Petrov, N.I. Barkov, L.I Sukhonosova, D.N. Dmitriyev, and V.G. Portnov. 1978 Reul'taty izucheniya vertikal'noy struktury lednikovogo pokrova Antarktidy $v$ rayone Stantsii Vostok [Results of vertical structure of the Antarctic ice sheet in Vostok
Station area]. Inf. Byull. Sov. Antarkt. Eksped. 97, 135-148.

Legrand, M., C. Lorius, N.I. Barkov, and V.N. Petrov. 1988. Vostok (Antarctica) ice core: atmospheric chemistry changes over the last climatic cycle (160,000 years). Atmos. Environ., 22(2), 317-331.

Lile, R.C. 1978. The effect of anisotropy on the creep of polycrystalline ice. J. Glaciol., 21(85), 475-483.

Lliboutry, L. and P. Duval. 1985. Various isotropic and anisotropic ices found in glaciers and polar ice caps and their corresponding rheologies. Ann. Geophys., 3(2), 207-224.

Lorius, C., and 6 others. 1985. A 150,000 year climatic record from Antarctic ice. Nature, 316(6029), 591-596.

Petit, J.R., P. Duval, and C. Lorius. 1987. Long-term climatic changes indicated by crystal growth in polar ice. Nature, 326(6108), 62-64.

Pimienta, P. Unpublished. Étude du comportement mécanique des glaces polycrystallines aux faibles contraintes: applications aux glaces des calottes polaires. (Thèse, l'Université Joseph Fourier, Grenoble I, 1987.)

Pimienta, P. and P. Duval. 1987. Rate controlling processes in the creep of polar glacier ice. J. Phys. (Paris), 48, Colloq. C1, 243-248. (Supplément au 3.)

Pimienta, P., P. Duval, and V.Ya. Lipenkov. 1987. Mechanical behavior of anistropic polar ice. International Association of Hydrological Sciences Publication 170 (Symposium at Vancouver 1987 - The Physical Basis of Ice Sheet Modelling), 57-66.

Pimienta, P., P. Duval, and V.Ya. Lipenkov. 1988. Mechanical behavior of ice along the $2040 \mathrm{~m}$ Vostok core, Antarctica. Ann. Glaciol., 10, 137-140.

Russell-Head, D.S. and W.F. Budd. 1979. Ice-sheet flow properties derived from bore-hole shear measurements combined with ice-core studies. J. Glaciol., 24(90), $117-130$.

Saltykov, S.A. 1961. Stereometric metallography. Ohio, Wright Patterson Air Force Base. (Report M.C.L. 905/1-2.)

Saltykov, S.A. 1976. Stereometricheskaya metallografiya [Stereoscopic metallurgy]. Moscow, Metallurgiya.

Shoji, H. and C.C. Langway, jr. 1984. Flow behavior of basal ice as related to modeling considerations. Ann. Glaciol., 5, 141-148.

Shoji, H. and C.C. Langway, jr. 1987. Flow velocity profiles and accumulation rates from mechanical tests on ice core samples. International Association of Hydrological Sciences Publication 170 (Symposium at Vancouver 1987 The Physical Basis of Ice Sheet Modelling), 67-77.

Underwood, E.E. 1970. Quantitative stereology. Reading, Addison-Wesley.

Vostretsov, R.N., D.N. Dmitriyev, O.F. Putikov, K.V. Blinov, and S.V. Mitin. 1984. Osnovnyye resul'taty geofizicheskikh issledovaniy glubokikh skvazhin i ledyanogo kerna $v$ Vostochnoy Antarktide [The main results of geophysical studies of deep boreholes and the ice core in East Antarctica]. Materialy Glyatsiologicheskikh Issledovaniy 51, 172-178.

Young, N.W., M. Pourchet, V.M. Kotlyakov, P.A. Korolev, and M.B. Dyugerov. 1982. Accumulation distribution in the IAGP area, Antarctica: $90^{\circ} \mathrm{E}-150^{\circ} \mathrm{E}$. Ann. Glaciol., 3, $333-338$. 